\title{
Effect of metal concentration on growth and luminescence of luminous bacteria strains isolated from golfo de Nicoya, Costa Rica
}

\section{Efecto de la concentración de metales en el crecimiento y la luminiscencia de cepas de bacterias luminiscentes aisladas del golfo de Nicoya, Costa Rica}

\author{
Luis Vega-Corrales ${ }^{1 *} \&$ Carolina Marín-Vindas ${ }^{1,2}$
}

\begin{abstract}
Luminescence in bacteria is catalyzed by luciferase. When these microorganisms are exposed to toxic substances, the bioluminescent enzyme system can be inhibited. The objective of this study was to analyze the potential that these microorganisms offer as native bioindicators of coastal marine pollution. The dynamics of luminescence intensity by visual classification and the effect of metal concentration on the growth and luminescence of 25 strains of luminescent bacteria, isolated during 2016 from seawater samples from the gulf of Nicoya, Costa Rica, was evaluated by the disk diffusion method. The sensitivity of each strain to different concentrations $(0.1,0.5$ and $1 \mathrm{mg} \mathrm{mL}^{-1}$ ) of $\mathrm{Cd}, \mathrm{Cu}, \mathrm{Cr}, \mathrm{Pb}$ and $\mathrm{Zn}$ was determined by its bioluminescent phenotype. In susceptible strains, a range of metal concentrations less than the growth inhibitory concentration affected the expression of luminescence. Strains with intense luminescence and defined zones of luminescence inhibition were considered to have greater potential as native bioindicators for monitoring environmental toxicity. More studies are required to determine the minimum concentrations that inhibit growth and luminescence with respect to the tested metals and other potentially toxic substances for the coastal marine ecosystems of Costa Rica.
\end{abstract}

Keywords: ecotoxicology, indicator species, luminous organism, marine biotechnology, luminous organism

\section{RESUMEN}

La luminiscencia en bacterias es catalizada por la luciferasa. Cuando estos microorganismos se exponen a sustancias tóxicas, el sistema enzimático bioluminiscente puede ser inhibido. El objetivo de este estudio fue analizar el potencial que tienen estos microorganismos, como

1 Laboratorio de Microbiología Marina (LaMMar), Estación de Biología Marina Juan Bertoglia Richards, Escuela de Ciencias Biológicas, Universidad Nacional, Puntarenas, Costa Rica. luis.vega.corrales@una.ac.cr* ORCID: https://orcid.org/0000-0003-3389-4373

2 Departament de Biologia Marina i Oceanografia, Institut de Ciències del Mar, CSIC, Barcelona, Catalunya, Spain. carolina.marin.vindas@una.ac.cr ORCID: https://orcid.org/0000-0002-9013-2378 
bioindicadores nativos de contaminación marino costera. La dinámica de la intensidad de la luminiscencia por clasificación visual y el efecto de la concentración de metales en el crecimiento y la luminiscencia de 25 cepas de bacterias luminiscentes, aisladas durante el 2016, a partir de muestras de agua marina del golfo de Nicoya, Costa Rica, fue evaluada por el método de difusión en disco. La sensibilidad de cada cepa a diferentes concentraciones $\left(0.1,0.5\right.$ y $\left.1 \mathrm{mg} \mathrm{mL}^{-1}\right) \mathrm{de} \mathrm{Cd}, \mathrm{Cu}$, $\mathrm{Cr}, \mathrm{Pb}$ y $\mathrm{Zn}$ fue determinada por su fenotipo bioluminiscente. En las cepas sensibles, un rango de concentraciones del metal menor a la concentración inhibitoria del crecimiento afectó la expresión. Se consideró que las cepas con luminiscencia intensa y zonas de inhibición de luminiscencia esta, definidas, tienen un mayor potencial como bioindicadores nativos para la vigilancia de la toxicidad ambiental. Se requieren más estudios para determinar las concentraciones mínimas que inhiben el crecimiento y la luminiscencia con respecto a los metales analizados y demás sustancias, potencialmente tóxicas, para los ambientes marino costeros de Costa Rica.

Palabras claves: biotecnología marina, contaminación marina, ecotoxicología, especies indicadoras, organismos luminiscentes

\section{INTRODUCTION}

Most luminous bacteria, which are widely distributed in marine environments, are taxonomically classified as belonging to Aliivibrio, Vibrio, and Photobacterium genera from the Vibrionaceae family. Several of these bacteria emit high levels of light easily visible in laboratory cultures. Luminescence in these microorganisms is produced by the expression of lux genes, and the light emission reaction is catalyzed by luciferase (Dunlap \& Urbanczyk, 2013).

Luciferase synthesis and luminescence in these bacteria is regulated by population density through a system called quorum sensing (Dunlap \& Urbanczyk, 2013). Hence, there is a relationship between the emission of luminescence with cellular metabolism. The bioluminescent enzyme system can be inhibited by exposing bacteria to toxic substances, and the intensity of light decreases quickly. Measuring the light intensity of bacteria exposed to different concentrations of a substance is used to evaluate its toxicity (Ma et al. 2014). Sensitive, repeatable, and easy to transport luminous bacteria-based assays have been developed to detect environmental contaminants (Camanzi et al. 2011; Bolelli et al. 2016).

Therefore, luminous bacteria have been used as bioindicators in assessments of environmental pollution (Burga et al. 2012; Ma et al. 2014), toxicity evaluation of pharmaceutical wastewater (Yu et al. 2014) and toxicological tests to assess pollution caused by metals, pesticides, and antibiotics in aquatic systems (Ranjan et al. 2012; Shanware et al. 2013). Moreover, Bagordo et al. (2012) have used them to assess anthropogenic impacts on estuarine ecosystems. 
Luminous bacteria represent a powerful tool for the initial assessment of environmental samples or substances with unknown ecotoxicological or toxicological characteristics (Menz et al. 2013). In Costa Rica, there are no references of bioassays to assess the effect that toxic compounds might be causing in coastal marine ecosystems and, according to Diepens et al. (2014), promotion of ecotoxicological assessments in the country using native species is required. This study aimed to analyze the effect of metal concentration on growth and luminescence of luminous bacteria strains isolated from the golfo de Nicoya, Costa Rica, to generate base information about the application that these microorganisms have as native bioindicators of coastal marine pollution in the country.

\section{MATERIALS AND METHODS}

In 2016, twenty-five (25) luminous bacteria strains isolated from surface seawater samples collected at the golfo de Nicoya, Costa Rica, were used. These strains were isolated using Marine Agar (MA) (Difco $\left.{ }^{\circledR}\right)$ and stored in Brain Heart Infusion (OXOID $\left.{ }^{\circledR}\right)$ with $20 \%$ glycerol at $-80^{\circ} \mathrm{C}$ until they were tested. These strains were numerically identified in a consecutive manner using the CL prefix.

Strains were characterized according to growth and luminescence intensity by visual classification following the methodology proposed by Kumar et al. (2015), with some variations. Every $2 \mathrm{~h}$ during a $14 \mathrm{~h}$ period, a record was made of growth and luminescence intensity of each strain inoculated by streaking swabs on MA plates (Difco () from a cell suspension equivalent to a $0.5 \mathrm{McF}$ arland standard in distilled water with $2 \% \mathrm{NaCl}$ prepared from an overnight MA plate. At the end of the incubation period and according to the final luminescence intensity, the strains were classified as intense, reduced, or $\mathrm{dim}$, based on the luminescence intensity scale defined in Fig. 1.

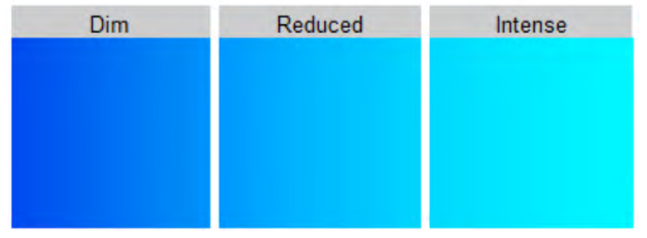

Fig. 1. Luminescence intensity scale defined for the classification of luminous bacteria strains isolated from the golfo de Nicoya, Costa Rica

Fig. 1. Escala de la intensidad de luminiscencia definida por la clasificación de las cepas de bacterias bioluminiscentes aisladas del golfo de Nicoya, Costa Rica

The effect of metal concentration on growth and luminescence of these strains was assessed using the disk diffusion method. Each luminous strain was inoculated by streaking swabs in MA plates plates from a cell suspension equivalent to a 0.5 McFarland standard in distilled water with $2 \% \mathrm{NaCl}$. Thereafter that, $6 \mathrm{~mm}$ 
diameter Whatman \#3 filter paper sterile disks were separately impregnated each with $10 \mu \mathrm{L}$ of $0.1,0.5$, and 1 $\mathrm{mg} \mathrm{mL}^{-1}$ metal ion solutions; namely, cadmium $(\mathrm{Cd})$, copper $(\mathrm{Cu})$, chromium $(\mathrm{Cr})$, lead $(\mathrm{Pb})$, and zinc $(\mathrm{Zn})$, then they were aseptically dried at room temperature and placed on the agar surface. Disks impregnated with 10 $\mu \mathrm{L}$ of sterile distilled water were used as negative controls. Tests were performed duplicate. Plates were incubated in the dark at $30^{\circ} \mathrm{C}$ for $24 \mathrm{~h}$.

After the incubation period, records were made concerning the diameter in $\mathrm{mm}$ of the growth inhibition zones (in the light) and the diameter in $\mathrm{mm}$ of the luminescence inhibition zones (in the dark). Every $2 \mathrm{~h}$ during $14 \mathrm{~h}$ of incubation, a photographic record was also made of the assay with Cd for CL4 and CL22 strains to illustrate the results. Photographs were taken in the dark with a $30 \mathrm{~s}$ exposure and under the same conditions (ISO500, F8) for comparison.

Mean difference and 95\% confidence intervals were calculated between the diameters for inhibition zones of growth or luminescence by metals and metal ion concentration. Samples mean pair-wise comparisons were evaluated using a t-test $(P<0.05)$. In a case were the statistical assumption (t-test) was not meet the non-parametric Wilcoxon test was applied $(P<0.05)$. Results were analyzed and plotted using $\mathrm{R}(\mathrm{R}$ Core Team, 2018).

\section{RESULTS}

The luminescence intensity scale is shown in Fig. 1. All strains grew $4 \mathrm{~h}$ after the incubation time started, and showed luminescence from 6 to $8 \mathrm{~h}$ after the start of the incubation (Fig. 2). The luminous strains assessed did not show growth and luminescence inhibition zones for the tested $\mathrm{Cr}$ concentrations. CL6, CL11, CL12, and CL19 strains showed dim luminescence (Fig. 2), and no inhibition zones (growth o luminescent) were observed (Fig. 5).

CL1, CL4, CL5, CL21, CL23, CL24, and CL25 strains showed reduced luminescence intensities (Fig. 2) and undefined luminescence inhibition zones. Only a degradation in luminescence (Fig. 3) was observed mainly around disks impregnated with $\mathrm{Cd}$ and with $1 \mathrm{mg} \mathrm{mL}^{-1}$ of $\mathrm{Cu}, \mathrm{Pb}$, and Zn (Fig. 4). CL2 showed intense luminescence (Fig. 1.), and undefined luminescence inhibition zones for $\mathrm{Cd}$, $\mathrm{Pb}$, and $\mathrm{Zn}$ (Fig. 4.). Growth inhibition zones were registered for CL1, CL2, CL4, CL5, CL21, and CL25 strains only in the $1 \mathrm{mg} \mathrm{mL}^{-1}$ concentration of $\mathrm{Cd}$; the mean of the diameter of the inhibition zones was $8,10,10,11.5,10$, and $10.5 \mathrm{~mm}$, respectively. 
Luminescence Intense $\bigcirc$ Reduced $O$ Dim

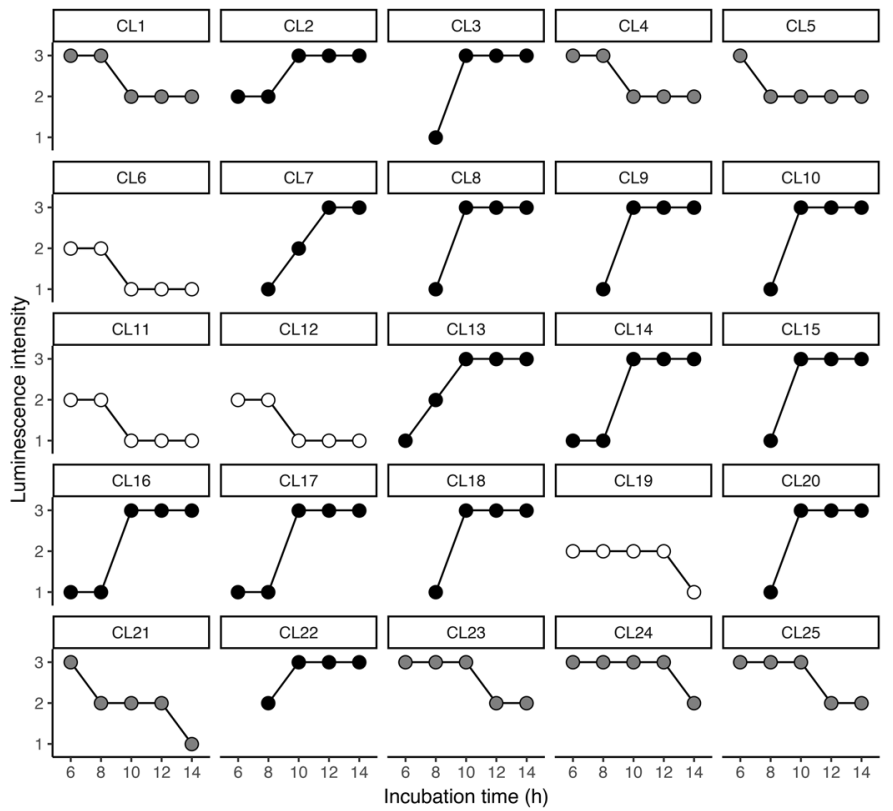

Fig. 2. Dynamic of luminescence intensity by incubation time (h) of luminous bacteria strains isolated from the golfo de Nicoya, Costa Rica. Strains are classified, according to the final luminescence intensity, as intense, reduced, or dim

Fig. 2. Dinámica en la intensidad de luminiscencia por tiempo de incubación (h) de las cepas de bacterias bioluminiscentes aisladas del golfo de Nicoya, Costa Rica. Las cepas se clasificaron de acuerdo con la intensidad de luminiscencia final como intensa, reducida o tenue

After the incubation period, CL3, Cd, $1 \mathrm{mg} \mathrm{mL}^{-1}$ of $\mathrm{Zn}$, and minimum CL7, CL8, CL9, CL10, CL13, CL14, diameters of $7 \mathrm{~mm}$ for $1 \mathrm{mg} \mathrm{mL}^{-1}$ conCL15, CL16, CL17, CL18, CL20, and CL22 strains showed intense luminescence (Fig. 2) and defined luminescence inhibition zones (Fig. 3).

The diameters of the inhibition zones (growth and luminescence) were very similar, and the averages were used (Fig. 5). Most of the strains showed growth inhibition zones for 0.5 and $1 \mathrm{mg} \mathrm{mL}^{-1}$ concentrations of centration of $\mathrm{Cu}$ and $\mathrm{Pb}$ (Fig. 5).

Those as mentioned above showed luminescence inhibition zones concerning $\mathrm{Pb}$ at all assayed concentrations. These strains showed defined luminescence inhibition zones for 0.5 and $1 \mathrm{mg} \mathrm{mL}{ }^{-1} \mathrm{Cd}$ and $\mathrm{Zn}$, respectively. Only CL15 and CL17 strains showed the same condition for $0.1 \mathrm{mg} \mathrm{mL}^{-1}$ Cd. CL9, CL10, and CL17 strains also 


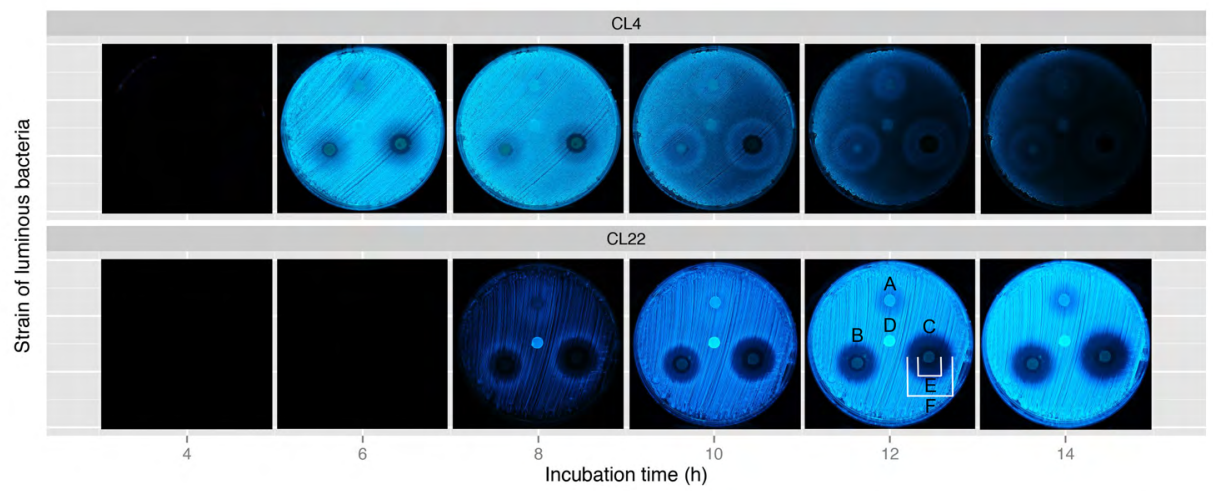

Fig. 3. Photographical record of the effect of 0.1 (A), 0.5 (B), and 1 (C) $\mathrm{mg} \mathrm{mL}^{-1}$ cadmium on the variation of luminescence intensity for CL4 and CL22 luminous strains at different incubation times. D = control. Strain CL4 exhibits a degradation of luminescence around disks impregnated with Cd; strain CL22 shows defined growth inhibition zones (E) and luminescence inhibition zones (F) for 0.5 and $1 \mathrm{mg} \mathrm{mL}^{-1} \mathrm{Cd}$ Fig. 3. Registro fotográfico del efecto de 0.1 (A), 0.5 (B) y 1 (C) $\mathrm{mg} \mathrm{mL}^{-1}$ de cadmio en la variación de la intensidad de la luminiscencia para las cepas luminiscentes CL4 y CL22 a diferentes tiempos de incubación. $\mathrm{D}$ = control. La cepa CL4 muestra degradación de la luminiscencia alrededor de los discos impregnados con Cd, y la cepa CL22 muestra zonas de inhibición del crecimiento (E) y zonas de inhibición de la luminiscencia $(\mathrm{F})$ definidas para concentraciones de $\mathrm{Cd}$ de 0.5 y $1 \mathrm{mg} \mathrm{mL}^{-1}$

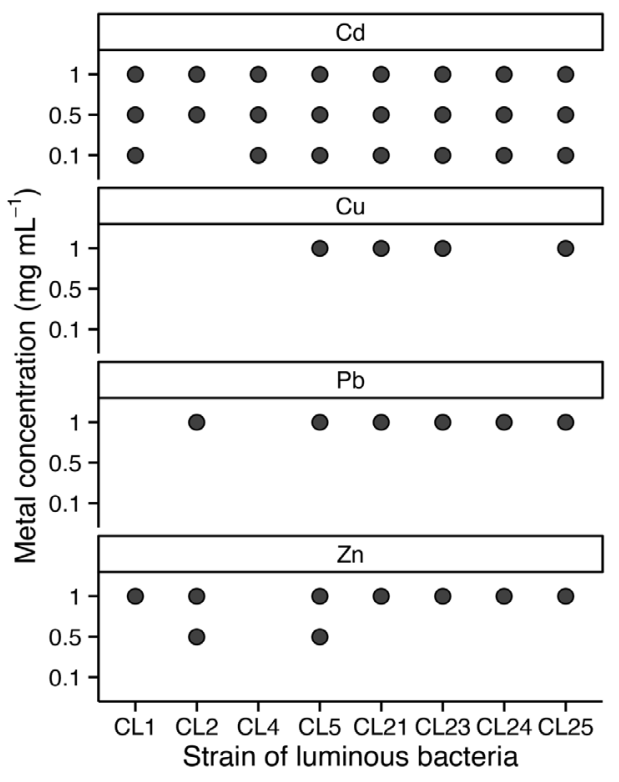

Fig. 4. Luminescence reduction $(\bullet)$ by different concentrations $\left(\mathrm{mg} \mathrm{mL}^{-}\right.$ $\left.{ }^{1}\right)$ of cadmium, copper, lead, and zinc ions on bacterial strains with reduced luminescence intensity isolated from the golfo de Nicoya, Costa Rica. Data for chromium ions not shown due to the absence of growth and luminescence inhibition zones

Fig. 4. Reducción de luminiscencia $(\bullet)$ por concentración $\left(\mathrm{mg} \mathrm{mL}^{-1}\right)$ de cadmio, cobre, plomo y zinc de cepas bacterianas con intensidad de luminiscencia reducida aislada del golfo de Nicoya, Costa Rica. No se muestran los ensayos con cromo debido a que no se observaron halos de inhibición de luminiscencia ni de crecimiento 
Metal: $\bigcirc \mathrm{Cd} \Delta \mathrm{Cu} \nabla \mathrm{Pb} \bigcirc \mathrm{Zn}$

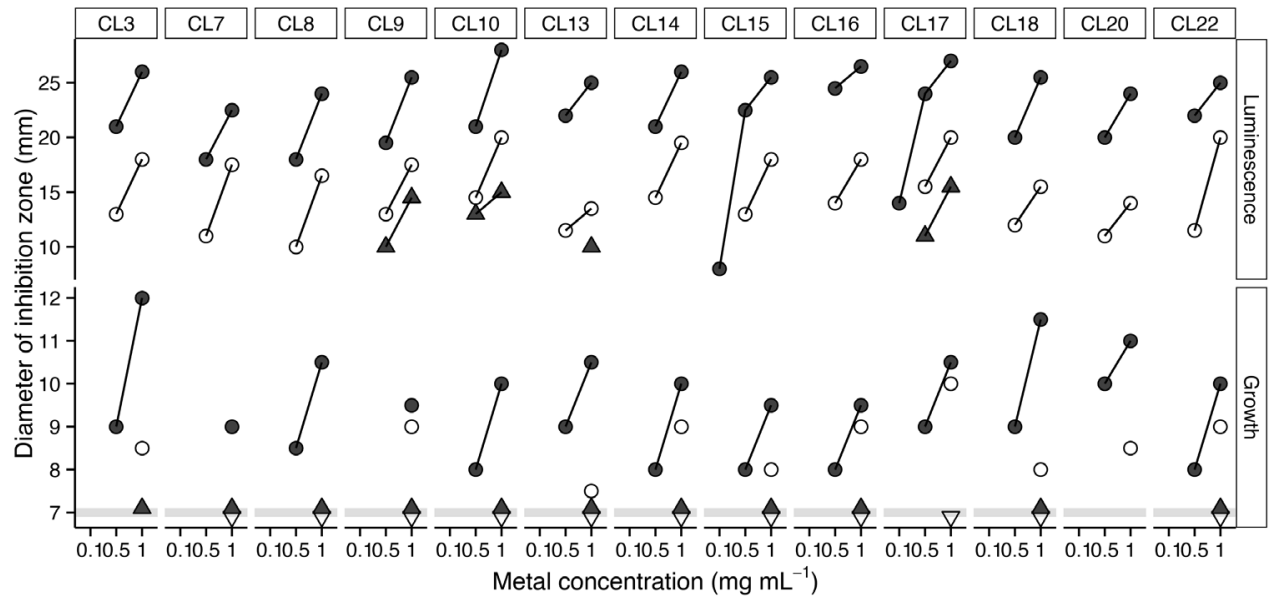

Fig. 5. Diameter (average of duplicates) of the growth and luminescence inhibition zone $(\mathrm{mm})$ for different concentration $\left(\mathrm{mg} \mathrm{mL}^{-1}\right)$ of cadmium, copper, lead, and zinc ions of bacterial strains with intense luminescence isolated from the golfo de Nicoya, Costa Rica. The diameters of the growth inhibition zones $(\mathrm{mm})$ for $\mathrm{Cu}$ and $\mathrm{Pb}$ are the same. Strains with dim luminescent (CL6, CL11, CL12, and CL19) did no exhibit growth or luminescent inhibition zones

Fig. 5. Diámetro (promedio de las réplicas) de las zonas de inhibición de crecimiento y de luminiscencia $(\mathrm{mm})$ por concentración $\left(\mathrm{mg} \mathrm{mL}^{-1}\right)$ de cadmio, cobre, plomo y zinc de cepas bacterianas con luminiscencia intensa aisladas del golfo de Nicoya, Costa Rica. El diámetro de las zonas de inhibición del crecimiento $(\mathrm{mm})$ para $\mathrm{Cu}$ y $\mathrm{Pb}$ es el mismo. Las cepas con luminiscencia tenue (CL6, CL11, CL12 and CL19) no mostraron zonas de inhibición de crecimiento o luminiscencia

showed luminescence inhibition zones for 0.5 and $1 \mathrm{mg} \mathrm{mL}^{-1} \mathrm{Cu}$, while CL13 strain only for $1 \mathrm{mg} \mathrm{mL}^{-1} \mathrm{Cu}$ (Fig. 5).

Strains affected by two or more concentrations of the same metal showed a directly proportional relationship between the diameter of the growth and luminescence inhibition zones and the corresponding metal concentration. CL9, CL10, CL13, and CL17 strains showed that diameters of the luminescence inhibition zones vary in the order of $\mathrm{Cd}>\mathrm{Zn}>\mathrm{Cu}$ (Fig. 5).

The mean difference between inhibition zones of growth or luminescence by metal and metal concentration is shown in Table 1. According to the statistical tests, growth inhibition zones by $\mathrm{Cd}$ and luminesce inhibition zones by $\mathrm{Zn}$ and $\mathrm{Cd}$ were significantly higher at $1 \mathrm{mg} \mathrm{mL}^{-1}$ than $0.5 \mathrm{mg}$ $\mathrm{mL}^{-1}$ for each metal. Luminescence 
Table 1. Pair-wise comparison between the diameter of the growth inhibition zone or luminescence inhibition zone caused by different metals at different concentration $\left(\mathrm{mg} \mathrm{mL}^{-1}\right)$ levels upon luminous bacteria strains isolated from golfo de Nicoya, Costa Rica

Cuadro 1. Comparación por pares entre el diámetro de las zonas de inhibición del crecimiento o zonas de inhibición de luminiscencia causada por distintos metales a diferentes concentraciones (mg mL-1) sobre las cepas de bacterias luminiscentes aisladas del golfo de Nicoya, Costa Rica

\begin{tabular}{|c|c|c|c|c|}
\hline \multicolumn{3}{|l|}{ Comparison } & \multirow{2}{*}{$\begin{array}{l}\text { Mean difference } \\
\mathrm{mm}( \pm 95 \% \mathrm{CI})\end{array}$} & \multirow{2}{*}{$\begin{array}{l}\text { Significance } \\
(P<0.05)^{* *}\end{array}$} \\
\hline Inhibition & Metal & $\mathrm{mg} \mathrm{mL}^{-1}$ & & \\
\hline \multirow[t]{2}{*}{ Growth:Growth } & $\mathrm{Cd}: \mathrm{Cd}$ & $1: 0.5$ & $1.86(1.49,2.23)$ & 1 \\
\hline & $\mathrm{Cd}: \mathrm{Zn}$ & $1: 1$ & $1.75(0.85,2.65)$ & 0 \\
\hline \multirow[t]{4}{*}{ Luminescence:Luminescence } & $\mathrm{Cd}: \mathrm{Cd}$ & $1: 0.5$ & $4.38(3.47,5.30)$ & 1 \\
\hline & $\mathrm{Zn}: \mathrm{Zn}$ & $1: 0.5$ & $4.88(3.87,5.90)$ & 1 \\
\hline & $\mathrm{Cd}: \mathrm{Zn}$ & $1: 1$ & $7.88(6.75,9.02)$ & 1 \\
\hline & $\mathrm{Cd}: \mathrm{Zn}$ & $0.5: 0.5$ & $8.38(7.46,9.31)$ & 1 \\
\hline \multirow[t]{3}{*}{ Luminescence:Growth } & $\mathrm{Cd}: \mathrm{Cd}$ & $1: 1$ & $15.15(14.22,16.09)$ & 1 \\
\hline & $\mathrm{Cd}: \mathrm{Cd}$ & $0.5: 0.5$ & $12.86(11.43,14.30)$ & 1 \\
\hline & $\mathrm{Zn}: \mathrm{Zn}$ & $1: 1$ & $8.75(7.41,10.09)$ & 1 \\
\hline
\end{tabular}

Notes: $* \mathrm{CI}=$ confidence interval; $* * 1$ and 0 denote significant and insignificant, respectively, at the 0.05 significance level.

inhibition zones for 1 and $0.5 \mathrm{mg} \mathrm{mL}^{-1}$ $\mathrm{Cd}$ and $1 \mathrm{mg} \mathrm{mL}^{-1} \mathrm{Zn}$ were statistically significantly higher than the corresponding growth inhibition zones. These strains showed higher luminescent inhibition zones $(P<0.05)$ by $\mathrm{Cd}$ than $\mathrm{Zn}$ at 0.5 and $1 \mathrm{mg} \mathrm{mL}^{-1}$. The difference for mean pair-wise comparison for growth inhibition zones by $\mathrm{Cd}$ and $\mathrm{Zn}$ at $1 \mathrm{mg} \mathrm{mL}^{-1}$ did not show a statistical significance.

\section{DISCUSSION}

This study's culture medium promoted the growth and luminescence of the tested strains; therefore, it was appropriate for the assays. Most research on luminous bacteria use the SWC (Seawater Complete) culture medium (Bagordo et al. 2012; Martini et al. 2013; Jabalameli et al. 2015) or culture media with a similar composition (Efremenko et al. 2014; Drozdov et al. 2015; Urbanczyk et al. 2015). In this study, strains grew over $(4 \mathrm{~h})$ in 
the Marine Agar (MA) and luminescence occurred 2 or $4 \mathrm{~h}$ later.

The assessment luminescence intensity dynamics of the assayed strains confirms that bacterial luminescence is an indicator of the activity of intracellular metabolic processes. The maximum luminescence intensity in a bacterial culture occurs during the exponential growth phase. Then luminescence dynamics is affected because of the reduction in metabolic processes kinetics (Drozdov et al. 2015). Efremenko et al. (2014) report that the luminescence intensity in free cells of Photobacterium phosphoreum decreases with time.

Differences between assessed strains in terms of luminescence duration and intensity coincide with the findings reported by Efremenko et al. (2014). The authors indicate that duration and intensity significantly differ between species and strains of the Photobacterium genus. In this way, the amount of light produced by luminous bacteria, even belonging to the same genus, makes these microorganisms show different bioluminescent phenotypes even though bioluminescence is regulated by a similar basic genetic system (Jabalameli et al. 2015).

Although the classification of the bioluminescence intensity used in this study is not a quantitative method, it is adequate for the determination of bacterial luminescence dynamics (mainly in solid culture media) without requiring specialized equipment. It could also be considered a useful technique for the screening of isolated strains and to define the optimal incubation period of each strain in view of evaluating the effects of toxic substances in solid-phase bioluminescence assays.

The luminescence inhibition rate of some bacterial strains has been used in toxicological and ecotoxicological assessments (Menz et al. 2013; Ma et al. 2014). Our results show that some metals at different concentration levels affect the growth and luminescence of luminous bacterial strains to different degrees. Also, we observed that the luminescence of some bacteria was inhibited by a metal ion concentration lower than the minimum growth inhibitory concentration.

The sensitivity of each strain to different concentrations of metal ions is determined by its bioluminescent phenotype and for practical bioassay applications the higher intensity luminescent strains with luminescence inhibition zones afford greater potential as pollution indicators. For example, strain CL17 that is potentially sensitive to cadmium at concentrations lower than $0.1 \mathrm{mg} \mathrm{mL}^{-1}$.

The intensity of the luminescence (in free and immobilized cells) decreases with increasing metal concentration. Kumar et al. (2015) reported the effect of copper and zinc at $1 \mathrm{mg}$ $\mathrm{mL}^{-1}$ on luminescence sensitivity of 20 
strains isolated from the Bay of Bengal While Efremenko et al. (2014) showed that luminescence intensity in cells of $P$. phosphoreum, immobilized in a polyvinyl alcohol cryogel, decreases with increasing metal ion concentration, and further concluded that metal toxicity for these immobilized cells varies in the order $\mathrm{Cu}^{+2}>\mathrm{Co}^{+2}>\mathrm{Hg}^{+2}$ $>\mathrm{Zn}^{+2}$. Our study reveals the order $\mathrm{Cd}$ $>\mathrm{Zn}>\mathrm{Cu}$, as well as the absence of luminescence inhibition by $\mathrm{Cr}^{+3}$ and $\mathrm{Pb}^{+2}$ at all the tested concentrations.

Many application tests employing luminous bacteria are known, and their distinctive features depend on the specific characteristics of the bacterial strain used. The isolation of native luminous bacteria allows bioprospecting for strains useful for monitoring environmental toxicity. Moreover, the isolation of strains of microorganisms resistant to metals is significant. The expectation is that microorganisms designated for bioremediation are tolerant of metals (Kumar et al. 2015).

\section{CONCLUSION}

Differences in luminescence intensity dynamics between strains, the definition of luminescence inhibition zones, and the determination of growth inhibition zone diameters and luminescence inhibition zone diameters for different metals ions at different concentration levels were determined.
For sensible strains, a range of concentrations of the metal ion lower than the growth inhibition concentration affected the expression of luminescence. Strains showing intense luminescence and defined luminescence inhibition zones were assigned greater application potential as bioindicators for environmental toxicity monitoring. However, more studies are required to determine the minimum growth and luminescence inhibition concentrations for the assayed metals ions and other substances potentially toxic to coastal marine ecosystems in Costa Rica.

\section{ACKNOWLEDGEMENTS}

This research was funded by the Ley de Pesca y Acuicultura (Fishery and Aquaculture Act) from the Government of Costa Rica as part of the project entitled "Distribución y abundancia de bacterias luminiscentes y su potencial como indicadoras de contaminación en el Golfo de Nicoya, Costa Rica" (Distribution and abundance of luminous bacteria and their potential as pollution indicators in the Golfo de Nicoya, Costa Rica), UNASIA-0338-13. Special thanks to Oscar Pacheco Prieto for taking the photographs and two anonymous reviewers for improving the manuscript. 


\section{REFERENCES}

Bagordo, F., Serio, F., Lugoli, F., Idolo, A., Gabutti, G. \& De Donno, A. (2012). Phenotypic characterization of culturable marine luminous bacteria isolated from coastal waters of the southern Adriatic Sea (Otranto, Italy). Cienc. Mar., 38(4), 599-608. https://doi. org/10.7773/cm.v38i4.2119

Bolelli, L., Ferri, E. N.\& Girotti, S. (2016). The management and exploitation of naturally light-emitting bacteria as a flexible analytical tool: A tutorial. Analytica Chimica Acta., 934, 22-35. https://doi. org/10.1016/j.aca.2016.05.038

Burga, K. F., Charlatchka, R., Sahli, L. \& Férard, J. (2012). New methodological improvements in the Microtox ${ }^{\circledR}$ solid phase assay. Chemosphere., 86, 105-110. https://doi.org/10.1016/j. chemosphere.2011.08.042

Camanzi, L., Bolelli, M., Girotti, S. \& Matteuzzi, D. (2011). Optimal conditions for stability of photoemission and freeze drying of two luminescent bacteria use in a biosensor. Environ. Toxicol. Chem., 30(4), 801-805. https://doi. org/10.1002/etc.452

Diepens, N. J., Pfenning, S., Van den Brink, P. J., Gunnarsson, J. S., Ruepert, C. \& Castillo, L. E. (2014). Effect of pesticides used in banana and pineapple plantations on aquatic ecosystems in Costa Rica. J. Environ. Biol., 35(1), 73-84.

Drozdov, A. V., Gromozova, E. N. \& Gretsky, I. A. (2015). An analisys of the bioluminescence intensity dynamics of the luminous bacteria Photobacterium phosphoreum, 60(2), 251-255. https:// doi.org/10.1134/S0006350915020050

Dunlap, P. V. \& Urbanczyk, H. (2013). Luminous Bacteria. In E., Rosenberg E.F., DeLong S., Lory E.
Stackebrandt \& F. Thompson (Eds), The Prokaryotes. (4th, pp. 495528). Springer, Germany. https://doi. org/10.1007/978-3-642-30141-4_75

Efremenko, E. N., Senko, O. V., Aleskerova, L. E., Alenina, K. A., Mazhul, M. M. \& Ismailov, A. D. (2014). Biosensors based in luminous bacteria Photobacterium phosphoreum imobilized in polyvinil alcohol cryogel for the monitoring of ecotoxicants. Applied Biochem. Microbiol., 50(5), 477-482. https://doi. org/10.1134/S0003683814050032

Jabalameli, L., Razavi, M. R., Hosseinkhani, S. \& Akhavan Sepahi, A. (2015). Isolation, identification and characterization of new luminous bacteria from Chah Bahar Port, southern marine habitat of Iran. Iranian J. Fish. Sci., 14(3), 555-566.

Kumar, A. R., Jayaprakashvel, M., FeuK-Lagerstedt, E. \& Hussain, A. J. (2015). Factors affecting bioluminescence in free living Photobacterium spp. Isolated from Bay of Bengal, India. J. Mar. Biosci., 1(1), 33-49.

Ma, X. Y., Wang, X. C., Hao, H., Guo, W., Wu, M. N. \& Wang, N. (2014). Bioassay based luminescent bacteria: interferences, improvements, and applications. Sci. Total Environ., 468469, 1-11. https://doi.org/10.1016/j. scitotenv.2013.08.028

Martini, S., Al Ali, B., Garel, M., Nerini, D., Grossi, V., Pacton, M., \& Tamburini, C. (2013). Effects of hydrostatic pressure on growth and luminescence of a moderately-piezophilic luminous bacteria Photobacterium phosphoreum ANT2200. PLoS One, 8(6), e66580. https:// doi.org/10.1371/journal.pone.0066580

Menz, J., Schneider, M. \& Kümmerer, K. (2013). Toxicity testing with luminescent bacteria- Characterization of an automated method for the 
combined assessment of acute and chronic effects. Chemosphere., 93(6), 990-996. https://doi.org/10.1016/j. chemosphere.2013.05.067

R Core Team. (2018). R: a language and environment for statistical computing. Austria: R Foundation for Statistical Computing. https://www.R-project. org/

Ranjan, R., Rastogi, N. K. \& Thakur, M. S. (2012). Development of immobilized biophotonic beads consisting of Photobacterium leiognathi for the detection of heavy metals and pesticide. J. Hazardous Mat., 225-226, 114-123. https:// doi.org/10.1016/j.jhazmat.2012.04.076

Shanware, A., Thakre, N. \& Pande, S. (2013). Isolation and characterization of novel marine luminescent bacteria from Diu beach, India. J. Pharm. Res., 7(6), 529-533. https://doi.org/10.1016/j. jopr.2013.05.019
Urbanczyk, Y., Ogura, Y., Hayashi, T. \& Urbanczyk, H. (2015). Description of a novel marine bacterium, Vibrio hyugaensis sp. nov., based on genomic and phenotypic characterization. System. Applied Microbiol., 38, 300-304. https://doi.org/10.1016/j. syapm.2015.04.001

Yu, X., Zuo, J., Tang, X., Li, R., Li, Z. \& Zhang, F. (2014). Toxicity evaluation of pharmaceutical wastewaters using the alga Scenedesmus obliquus and the bacterium Vibrio fischeri. J. Hazarduos Mat., 266, 68-74. https://doi. org/10.1016/j.jhazmat.2013.12.012 